\title{
Protection of Cultural Goods- Economics of Identity
}

\author{
Marianna Bicskei*
}

\section{Kilian Bizer}

\section{Zulia Gubaydullina}

\begin{abstract}
This article addresses the current international debate on the protection of cultural goods. Whereas some groups (such as indigenous peoples) are arguing for the creation of cultural property rights analogous to classic intellectual property rights such as patent and copyright, most industrialized countries advocate to keep cultural goods within the public domain. In this article, we develop an economic perspective based on identity and clarify the question of which cultural goods should be protected, regulated, or left in the public domain. We conclude that protection based on the concept of identity is required for a very limited scope of cultural goods.
\end{abstract}

\section{INTRODUCTION}

In the Intergovernmental Committee on Traditional Knowledge, Genetic Resources and Traditional Cultural Expressions of the World Intellectual Property Organization (WIPO-IGC), nations from all parts of the world are discussing

\footnotetext{
*University of Göttingen, Economic Policy and SME Research, Platz der Göttinger Sieben 3, 37073 Göttingen, Germany. Email: Marianna.Bicskei@wiwi.uni-goettingen.de

ACKNOWLEDGMENTS. This research is part of the Interdisciplinary Research Group on Cultural Property funded by Deutsche Forschungsgemeinschaft (DFG). We gratefully acknowledge the constructive comments by two anonymous referees, the editor Alexander Bauer, participants at the 2010 ACEI conference in Copenhagen, the Società conference at the University of Vienna, and the International Symposium on Cultural Property in Göttingen. We are also grateful for many helpful discussions and comments by Regina Bendix, Ejan Mackaay, Dorothy Noyes, Rosemary J. Coombe, and the Interdisciplinary Cultural Property Research Group.
} 
whether to provide more protection for cultural goods. In the Convention on the Protection and Promotion of the Diversity of Cultural Expressions, the United Nations undertook "to protect and promote the diversity of cultural expressions, ... and to give recognition to the distinctive nature of cultural activities, goods and services as vehicles of identity, values and meaning." ${ }^{1}$ Moreover, the protection of culture is part of the international agenda in different aspects and constellations. How can this be interpreted from an economic point of view?

Many cultural expressions, such as sacred rituals or sand paintings, play an important role in the identity of certain groups and should be protected from misappropriation and misuse. Such cultural practices might require specific protection measures.

While some countries would like cultural goods to receive more protection, other countries argue that cultural goods belong to the public domain. The latter argue that most, if not all, cultural goods should be available for everybody as long as standard intellectual property rights are not infringed upon. Take, for example, yoga as a meditation practice used around the world despite the fact that it originates in India. Should yoga be reserved for the Indian population only? Should everybody else be required to apply for a yoga permit or even pay a "yoga dime" for practicing it? ${ }^{2}$ As another example, take any language: Should someone willing to learn to speak it pay an additional charge or ask for permission because the language "belongs" to another culture?

Of course, many doubt that cultural expressions should be commodified at all. But in the contemporary world temples as well as their rituals, villages, or tribes and their celebrations, dances, theatre, or sacred drawings come to the attention of tourists, designers, and other outsiders and in practice are turned into commodities. In the process of commodification certain aspects of the culture may very well get lost. This loss may form the difference between the original cultural expression and the commodified one, and can be relevant for the identity of members of a specific group. Such loss can take the form of identity loss and thus serve as a source of justification for protecting cultural goods. We use the phrase cultural goods in what follows to direct our attention toward goods and services derived from culture in the broadest sense. In order to avoid misunderstanding, we do not use the term goods in any other sense.

In this article we analyze from an economic perspective whether cultural goods require further protection if we take effects on identity into account. We develop a framework allowing us to assess different effects on three of the most relevant groups affected by cultural goods. We distinguish these groups as culture carriers, outsider consumers, and culture reproducers, which are not the same as producers of classic goods and services. Such an assessment provides insights into the regulatory choice problem faced by national legislators as well as the international community, who intend to identify how much protection of cultural goods should be targeted in general. According to our analysis of the utility 
of cultural carriers, only cultural goods that are essential to identity and dignity require additional protection. This is due to the fact that culture reproducers and outsider consumers negatively affect the identity and thus the dignity of the culture carriers. In these cases, rights are required to exclude these actors from consumption and restrict the commodification of these particular cultural goods.

To investigate this topic, the rest of the article proceeds as follows: The second section discusses identity as an economic variable, which is said to determine the valuation of the protection of cultural goods. The third section deals with the utility derived from consuming and reproducing cultural goods. In the fourth and fifth sections, we address different protection issues regarding cultural goods while classifying cultural goods according to their direct and indirect effects. In the final section we arrive at several conclusions.

\section{PROTECTION OF CULTURAL GOODS-LITERATURE REVIEW}

In drawing on the concept of identity to develop an economic argument about the protection of cultural goods, we feel it is necessary to analyze identity in an economic context and incorporate identity into the economic (utility) function. This is necessary because identity is of high importance in a cultural context. To understand the behavior of individuals or groups, the impact of others on their identity must be scrutinized more deeply.

The descriptive literature on identity and its utility relies on the theses of Akerlof and Kranton, ${ }^{3}$ the most widely accepted account of the relationship between identity and economic outcomes. These authors suggest that identity might be recognized as a determinant factor in utility functions. In their model, the utility function $\left(U_{j}\right)$ consists of three variables. ${ }^{4}$ The first, identity or self-image $\left(I_{j}\right)$, is determined by social categories such as gender or occupation as well as their features and typical characteristics since members of a given social category or group are often expected to exhibit specific physical or cultural characteristics and attitudes. The second variable refers to a person's actions $\left(a_{j}\right)$ undertaken to maximize the person's own utility while complying with the prescriptions of his social category. The third identifies the actions of others $\left(a_{-j}\right)$, which, combined with the second variable, have an impact on a person's consumption of goods and services. It is assumed that a particular social category has an impact on a person's identity, thereby affecting the person's so-called identity-related behavior. ${ }^{5}$ Consequently, identity plays an important role in the utility function because a person's own actions affect the person's utility, which is to some extent based on the actions' impact on identity. According to the model of Akerlof and Kranton, identitybased payoffs can arise from a person's own actions as well as from those of others. The result is that the actions of others can affect a person's utility and identity at the same time, a finding that needs further investigation. 
In our article, we focus on the changes in utility caused by (other) third parties not belonging to the particular social category. According to the literature mentioned in the preceding paragraph, "those who try to change social categories and prescriptions may face similar derision because the change may devalue others' identity." 6 In the model of Akerlof and Kranton there is the possibility for a person to have a limited choice over his or her identity. They argue that without distinctive characteristics, it is possible to join other social categories, but also that this possibility is limited with respect to physical appearance or accent. We assume that different cultures, as a kind of social category not only sharing common characteristics but also constituting a social group, ${ }^{7}$ comprise individuals whose common features form a basis for their interaction with one other, and that these are fundamentally based on cultural goods. The consumption and production of cultural goods within a particular culture are based on the choices and actions of individuals or a group of individuals, which induce changes in their utility function and thus in their identity. According to this argument, the impact of cultural-goods-related actions by an outsider to the group on another person's group identity deserves further attention. In this context Akerlof and Kranton identify a loss of identity if somebody violates a person's internalized values ("prescriptions"). Therefore, these actions of others produce "externalities," against which there is no protection. Activities of persons related to cultural goods who are not members of the particular culture are the basis of our analysis. In our view, these actions may need to be regulated by institutions such as the World Intellectual Property Organization (WIPO).

The literature on cultural goods shows a broad scale of approaches mostly based on international trade. Francois and van Ypersele ${ }^{8}$ approach the issue of protecting cultural goods and their impact on welfare from a different perspective. Their work is based on the different valuation of cultural goods by insiders (home country) and outsiders (abroad), produced under economies of scale, and is exemplified by trade in movies. In their example, Hollywood films, which can unintentionally disturb traditional or indigenous cultures, are valued the same by both sides (local and foreign people). This means, for instance, that consumers in both the United States and France are willing to pay for consumption of Hollywood films. In contrast, the valuation of domestically produced films is not homogeneous between consumers at home and abroad. According to that example, not all French consumers prefer French auteur films or are willing to pay a premium for them. ${ }^{9}$ In their two-country (United States, France)/three-culturalgoods (mainstream Hollywood films, French auteur films, U.S. auteur films) model, they explore whether protection of cultural goods (in this case, auteur films) could increase welfare for all parties and whether it can be Pareto improving for all parties if countries introduce a cultural tariff on Hollywood films. If a tariff or quota is introduced, traditional film production, in which fixed costs are very high, would not be crowded out by blockbuster producers, whose market share takes up most of the world. From the perspective of domestic groups in 
both countries, the restriction would imply that the local auteur cinema would still be available for the local population, which values this good highly. Moreover, consuming locally produced goods is required in order to keep domestic culture alive. At the same time, export potential is provided, which increases the well-being of the population. In this article, great importance is attributed to the valuation of cultural goods. This valuation is fundamental to the different social groups and must be reflected when investigating the protection of cultural goods.

Another important contribution to the issue of protecting cultural goods is provided by Janeba, ${ }^{10}$ who analyzes the impact of free trade of cultural goods on cultural identity. In his article, cultural goods are defined as goods that interconnect individual consumption decisions and thus contribute to the formation of a cultural identity. For example, consuming a cultural good could make consumption more attractive for other consumers. Identity is built if all individuals within the society consume the same cultural good (a culturally homogeneous good). The identity function could be described as a network externality. For instance, Germans drink beer, which is identified as a common tradition in Germany. If everybody in the society consumes the same good, the loss in identity is zero, but consumption is influenced by the factors of price and social punishment. This consumption may change in the case of trade liberalization leading to changes in the homogeneous consumption behavior of a specific society, therefore causing a loss of identity. Janeba favors a protectionist approach toward cultural goods based on welfare analysis both in closed and open economies. Considering one model of international trade and assuming different technologies and economies of scale, he deducts inter alia that in the case of cultural homogeneity (homogeneous taste and consumption of cultural goods), trade cannot have a Pareto-improving effect on closed economies (autarky). In sum, the model demonstrates that while social consumption behavior changes due to the imported cultural goods, individuals consuming the exported good lose out on trade liberalization. Janeba argues that consumers of cultural goods produced and consumed locally are those that oppose trade liberalization the most. He further concludes that globalization has a negative impact on national culture and individual identities. In order to preserve a culture, the consumption of locally produced goods must be supported.

The public debate concerns the preservation of culture and cultural identity through the protection of cultural goods. The economic discussion takes this up while seeking the utility-providing effect of cultural goods. Against this background, we focus on the central question: What exactly is it that requires protection? We answer this question by introducing an economic approach to cultural goods and their protection. We suggest a set of criteria that help to determine whether a cultural good should be protected or not. These criteria include considerations of direct effects as well as indirect effects of cultural goods' consumption. We also distinguish between certain groups affected by the consumption and reproduction of cultural goods. 


\section{UTILITY FROM CULTURAL GOODS}

Culture is a phenomenon that is not easy to define. The United Nations define culture as "diverse forms across time and space; this diversity is embodied in the uniqueness and plurality of the identities and cultural expressions of the people and societies making up humanity." 11 We define culture within the scope of this article as a phenomenon consisting of different goods (cultural goods) that "are considered to consist of tangible and intangible items of cultural significance." 12 The specific feature of cultural goods lies above all in the fact that they must be treated as vectors of identity and not as mere commodities or consumer goods. ${ }^{13}$ Of course, immaterial cultural goods are more problematic, as most material goods are already protected by classic property rights, but both intangible and tangible parts of cultural goods are the subjects of our examination.

For our analysis, we introduce the notions of culture carriers, culture reproducers and outsider consumers (consumers others than culture carriers). Culture carriers are defined as the groups or individuals from whom the cultural good originates. They could also be called insiders, as they belong to the group or society $^{14}$ in which a certain cultural good emerges. As they are the holders and custodians of particular cultural goods, they consequently consist of both producers and consumers. They produce cultural goods that they sell as a private good and/or provide for the public domain. For simplicity of argumentation we refer to these insider actors as "culture carriers." As part of the group of outsiders, the so-called outsider consumers and the culture reproducer (reproducer of cultural goods) are defined as societies, groups, or individuals using the cultural good but who are entirely disconnected from its emergence. Both groups, insiders and outsiders (see figure 1), draw utility from cultural goods, and both groups value the cultural good in question positively.

Let us first take a closer look at the utility of culture carriers. To address this we introduce a "cultural utility function" of culture carriers who share the same cultural identity based on particular cultural goods. We assume that cultural goods

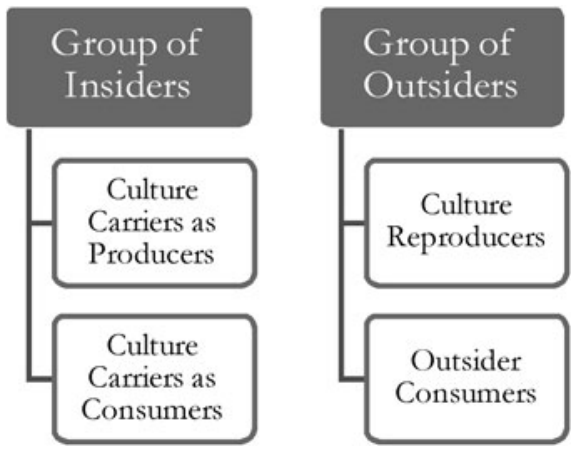

Figure 1. Classification of the actors in the categories of insider and outsider. 
provide both direct and indirect utility to culture carriers. The direct part of the utility includes monetary benefits from cultural goods. These arise when any outsider consumer is willing to pay for using a cultural good such as dancing lessons, a copy of a traditional pattern, music, or a picture of some historical monument produced by culture carriers. This utility can also be described as "direct consumption benefit" or "direct market benefit." ${ }^{15}$ Arguing in this manner, it is clear that if outsider consumers use a cultural good without paying for it, such as illegally uploading copyrighted cultural songs, it has a negative impact on the (direct) utility of the culture carrier who intended to sell it. In cases in which no income or revenue is generated, culture carriers might face the problem of not being able to recover the costs invested in the production of that cultural good. In the long run, this could have a negative effect on the incentives to create cultural goods. ${ }^{16}$ As a result, this can imply an overall economic loss. Moreover, if other individuals or groups other than culture carriers (defined as reproducers of cultural goods) begin to reproduce the same cultural goods without permission and seize benefits from them (copying a cultural song and selling it), it reduces the direct part of the utility of the culture carriers even more. ${ }^{17}$ These factors play a role above all when, for instance, immaterial property rights are infringed.

In our analysis from the regulatory perspective, the utility of outsider consumers and reproducers also plays an important role and must be considered within the direct component of the cultural utility function. ${ }^{18}$ Thus, if the culture carriers' direct utility decreases but is in turn overcompensated by the utility increase of the outsiders, it can be overall economically reasonable to allow for outside consumption. In other words, if the social costs ${ }^{19}$ restricting the outside consumption of the particular cultural good are greater than the social benefits, the economic reasoning is the same as in the case of monopoly regulation: Even if the monopolist loses his revenues, it makes sense to restrict his actions.

Let us turn our focus to the crucial part of the cultural utility function: the indirect component. Indirect utility is constituted of different effects, which, in sum, provide identity for the culture carriers. ${ }^{20}$ These effects include intrinsic values such as option, existence, bequest, prestige and education values. These are so-called nonmarket, nonuser benefits. ${ }^{21}$ The utility drawn from identity defined in this way enters the cultural utility function of the culture carriers. Identity as part of the utility function was already discussed by Akerlof and Kranton $^{22}$ in the labor market context and can also be applied to the cultural utility function. However, according to Throsby ${ }^{23}$ it is quite difficult to determine the value of identity in monetary terms because identity cannot be exchanged for other goods. This part of the cultural utility function is the most complicated one, as it consists of different effects. On the one hand, identity affects the consumption decisions of individuals and can therefore be seen as a consumption externality, similar to network externalities. ${ }^{24}$ Accordingly, it might simply mean the motivation to engage in and perform common practices or consume particular cultural goods. Moreover, on the other hand, some cultural 
goods could fundamentally affect the existential identity of a person, his dignity. Thus, destroying or misusing this kind of cultural good would imply a negative effect on the person's identity, thus causing a loss in utility. According to Harrison, ${ }^{25}$ identity-providing symbols (like cultural goods), which refer to all objects or customs used as signs or representatives of the social (cultural) identity, are validly authentic if maintained by the owners. ${ }^{26}$ The same actions by outsiders, however, are seen as imitations or as misappropriations of characteristics and qualities of the owner's group, which can be interpreted as a depreciation or devaluation of the identity. Consequently, the impact of outsiders, both on direct and indirect utility of the culture carriers, needs further investigation.

\section{CLASSIFICATION OF CULTURAL GOODS}

From an economic point of view, cultural goods can be classified according to the extent to which outsiders make use of them and in doing so affect the culture carriers' utility. Once the cultural utility functions are clearly stated, the question of protecting cultural goods can now be analyzed with the help of these as well as their relationships. Based on the described utility effects of cultural goods in section 3 , it is possible to divide them into different groups depending on the cultural outsiders' effect on the culture carriers' utility.

Thus, first with focus on direct utility, it can increase, decrease or remain unchanged as outsider consumers use cultural goods. Speaking of the indirect part of the cultural goods' utility-providing impact, the so-called identity-providing part, we scrutinize the effect of the cultural consumption by outsiders on indirect utility. According to that, cultural goods can be divided into three different types:

1. Cultural consumption by outsiders has a positive effect on the utility of culture carriers: The indirect utility of cultural goods rises with the number of other users. This type of cultural goods can be identified for example if the group "owning" this cultural good (culture carrier) is willing to disseminate it to other individuals, groups, or societies (to outsiders). For example, a language spoken by other groups produces network externalities; ${ }^{27}$ the adoption of a religion by another community ensures comparable values and norms, and the like. Christianity, which was and is disseminated actively by missionaries, is an example of such a cultural good from a Christian point of view. $^{28}$

2. The utility of cultural goods could also be independent of usage by outsiders. These kinds of cultural goods are rarely found. For example, Buddhism as a religion or spiritual philosophy is very peaceful. According to the doctrine of Buddhists, it is important to find the middle path in themselves and escape from negative feelings. The aim is to attain nirvana, but this path must be reached alone. Therefore, the fact that this religion is used by other than 
insider consumers does not have any effect whatsoever on Buddhists' indirect or direct utility.

3. The utility of cultural goods can diminish as outsider consumers use them. For example, if sacred rituals are performed by outsiders, they may lose their meaning for the culture carriers. According to de Beus, ${ }^{29}$ who investigated the impact of national identity, it can even influence their feeling of belonging, dignity, and identity. The question of what kinds of cultural goods have this strong identity or dignity-providing effect cannot be answered without analyzing particular cases. The secrecy of cultural goods can serve as an indication for this effect: Culture carriers trying to restrict the access of others (outsider consumers, or groups willing to produce the same cultural good) to their cultural good (and by no means aiming to sell this good themselves) could be seen as evidence in favor of protection. ${ }^{30}$ As "individuals are the best judges of their own welfare," 31 the effort to keep a cultural good secret indicates that it must have a large influence on their identity. An example for such a kind of cultural good is the turtle as a religious symbol of Ganalbingu people. This was misappropriated by an outsider textile producer which negatively affected the identity of that group. ${ }^{32}$ Mike Tyson or Robbie Williams wearing a Maori tattoo ${ }^{33}$ (moko) exemplify other cases in which outsider consumption of a particular cultural good negatively affects the indirect utility of culture carriers since ta moko illustrates identity and serves particular meaning such as recognition of difference by the Maori people. ${ }^{34}$ Accordingly, outsider consumption or production in the new context change "the meaning and significance" of these goods.

If we further differentiate between the direct and indirect utility of culture carriers, which can be positively or negatively affected by outsider consumption, we arrive at the classification presented in figure 2 .

The matrix in figure 2 combines the effects of outsiders' consumption and reproduction on the direct and indirect utility of culture carriers. The effect of cultural consumption or production by outsiders on the direct utility of culture carriers is shown on the $x$-axis, while the effects on indirect utility are depicted on the $y$-axis.

In the first quadrant (I) there is no need for any regulation, as both direct and indirect utility of culture carriers are positively affected by cultural outsider consumption. Additional cultural production has the same effect, as it generates additional cultural consumption, which again is positive.

An example is language as a part of culture. The culture carriers of a certain language could be interested in its dissemination and usage, as it facilitates trade between cultures and offers a possibility of reducing the costs of engaging third parties. ${ }^{35}$ A common language is necessary for international/domestic communication and trade, ${ }^{36}$ and the importance of it grows with time, so the effects in the long run as well as in the short run are positive. 


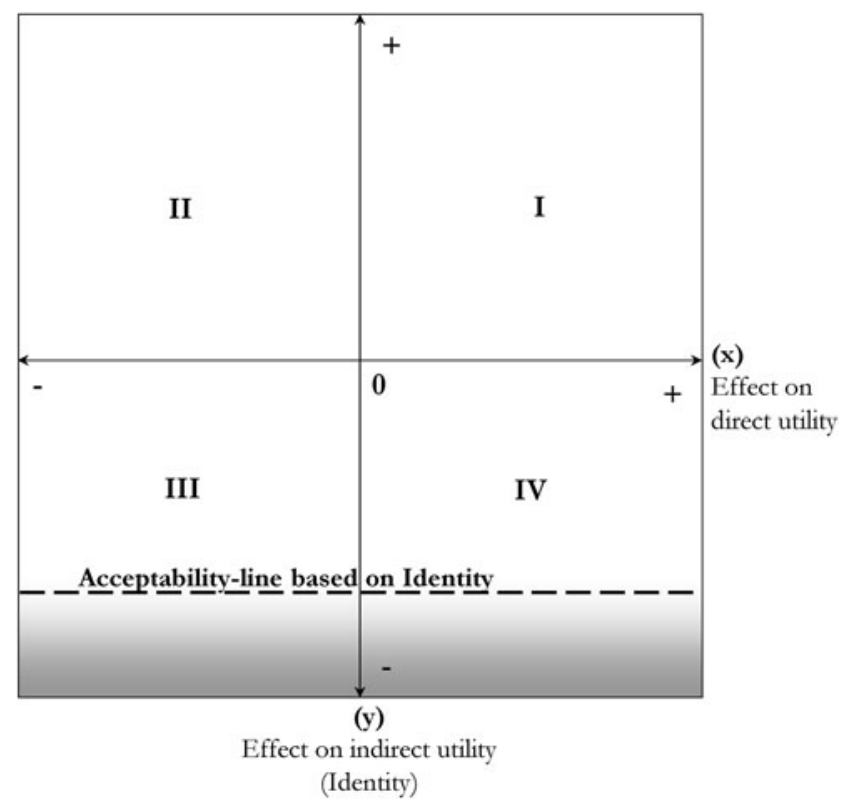

Figure 2. Utility effects on the culture carriers' utility caused by outsiders and the protection area for cultural goods (shaded).

In the second quadrant (II) the indirect utility is positive, while the direct utility of culture carriers is negatively affected by cultural outsider consumption. Therefore, the culture carriers' direct utility should be considered in comparison to the utility of outsider consumers and culture reproducers. Furthermore, the long-run welfare effects of consumption and additional production must be analyzed. In this part of the analysis, a detailed consideration of the culture carriers' direct utility, the outsider consumers' utility, and the culture reproducers' utility is necessary. If the only motivation of the culture carriers seeking protection of cultural goods is to maintain their monopolistic position regarding the production of cultural goods, it could be rational to allow other culture reproducers to enter the market and generate additional benefits for society. However, additional culture reproducers may increase the supply of cultural goods and achieve a sustained price reduction or may even destroy the good's cultural content, thus not implying any additional benefits for society in the long run. Or, in contrast, additional (re-)production of cultural goods by outsiders may act as a marketing tool to advertise and increase the value of the original cultural goods (made by culture carriers), thus creating or broadening the market for cultural products on the long run. ${ }^{37}$

Another possibility is that if the utility of outsider consumers exists only if culture carriers are the producers of a certain cultural good, then there is no need for regulation, as this feature of the utility function serves as an entry barrier for additional culture reproducers. However, the distinguishing character between an original or authentic (made by culture carriers) and a perfect copy (produced by an 
outsider) of a cultural good is questionable according to Mas-Colell. ${ }^{38}$ He argues that a perfect description of the object is infeasible and, accordingly, that the unique characteristics of an original are hard to identify. Valuations of the goods are dependent on the intrinsic motivation of both culture carriers and outsiders, but he argues that the owners are not always interested in preventing the property from being copied because the spreading of copies can still raise the value of the original (as already mentioned here).

In this quadrant, existing legal tools can be useful in solving the problem. For example, the system of fair trade ensures that goods from a particular part of the world that were produced according to the legality of fair trade cannot be produced and sold by another person who is not involved. ${ }^{39}$ Moral rights in, for instance, Australia or the United Kingdom give opportunities to creators to protect their integrity right and their work's underlying knowledge and content from infringement. ${ }^{40}$ This means that reproduction and alteration of the work is only allowed under the supervision of the author, which arguably prevents misuse and misrepresentation.

The history of origin of the Quileute in America can provide an example for this quadrant. Due to Stephenie Meyer's vampire chronicles, this group of people has become very well-known and famous. ${ }^{41}$ The Twilight story, which is based on the creation saga of the Quileute, has generated enormous revenues from books, movies, and other products. ${ }^{42}$ The Quileute have not profited from these activities as yet, although the core of these products is based on their cultural property. The fame of the Quileute has encouraged other producers (reproducers) to begin to use the name Quileute as a symbol for other products such as jewelry or hoodies without the permission of the Quileute. The Quileute are ready to share parts of their culture with outsiders with the exception of burial grounds and religious ceremonies, according to their tribal law, which are "sacred and not to be entered." 43 The situation, in which the Quileute wish to make their certain cultural goods publicly accessible and commercialize it to earn money, means that the influence of outsiders has no identitydestroying effect. The interest of these people lies above all in benefiting from the profit earned through their culture. From an identity-economic point of view, additional preventive measures are not necessary at this point.

The third quadrant (III) represents the most complicated cases in the analysis. The consumption and production of cultural goods by outsiders have negative effect on both direct and indirect utility of culture carriers.

It is very important to distinguish among different effects on indirect utility, because not every attack on identity immediately equals an attack on the dignity of a person. In other words, not every kind of cultural consumption and reproduction by outsiders that has a negative impact on indirect utility is at the same time a violation of dignity. For this reason, we separate the effects on indirect utility into two parts, which are divided by the acceptability-line (see figure 2). This acceptability-line varies from nation to nation (or culture to culture) according to their respective constitutional norms and the accompanying administration of justice. This line is a flexible concept; the definition of the exact position and mean- 
ing of this line reflects existing norms in society and could vary in different societies. It is therefore subject to discussions and judgments of courts of justice in a particular country. In short, "dignity does not depend on personal favours and occasional balances of power, but on social openness guaranteed by the rule of law, vigilant public debate, the plurality of associations, and social rights." ${ }^{4}$

The self-determination of a cultural group's own identity in accordance with their tradition and customs was recognized in the Declaration on the Rights of Indigenous Peoples of the United Nations. ${ }^{45}$ Furthermore, the connection between the culture and the dignity of the culture carriers was considered. According to this declaration, these groups "have the right on the dignity and diversity of their cultures, traditions, histories and aspirations." 46 Dignity is a person's fundamental right. Other fundamental rights such as privacy or religion are based on the concept of dignity. In the case when a cultural good is an inseparable component of a culture and the fundamental identity of the culture carriers is thereby influenced, the protectionworthiness of that cultural good would be corroborated. The position of the line reflecting these identity- and dignity-essential characteristics of the cultural goods is defined by an acceptance of those involved. Therefore, this line will take other positions within different cultures and cultural groups. This approach is supported by the following UN directive concerning Human Rights: "recognizing, respecting, valuing their customs, rules is essential to their identity, dignity." 47 This effect becomes disastrous below the acceptability-line on the basis of identity in figure 2 .

The gray shaded area below the acceptability-line contains those cultural goods that need protection on the basis of identity. Here, the effect of outsiders on the identity and the dignity of the culture carriers is so strong that the losses of the culture carriers cannot be tolerated any more. Therefore, protection is justified, as in these cases the dignity of a person is endangered.

Let us exemplify this by the original Hopi or Navajo tradition of sweat lodges, in which a cleansing of body and spirit takes place. According to the traditional tribal law, it was forbidden to charge any fees for this holy and intimate ceremony. ${ }^{48}$ The mere fact of outsiders consuming and even reproducing this sacral ritual resulted in an outcry by the indigenous people. Because it concerns a ritual, the Navajos are offended ${ }^{49}$ and suffer a loss in their identity if an outsider carries out the same ritual as a measure of well-being. From the point of view of indigenous leaders, "most hallowed ideas and rituals" constitute goods "which cannot diffuse to others without suffering harm." 50 Therefore, it seems obvious that cultural goods below the acceptability-line in this quadrant are in need of protection.

In cases above the acceptability-line, where the dignity, that is, the fundamental identity of a person or group, is not affected, an economic analysis can help to find an optimal solution. Therefore, there are three groups relevant to economic consideration $^{51}$ —culture carriers, culture reproducers, and outsider consumers. However, in connection with the direct, economic benefit, the United Nations stress that the cultural groups should be the beneficiaries of a commercial use of their cultural goods. ${ }^{52}$ 
The problem could consist in a positive correlation of the outsider consumers' utility with the importance of the cultural goods for the culture carriers, so that cultural goods with potential identity-destroying effects could be especially valuable to outsider consumers. ${ }^{53}$ Therefore, it is crucial to distinguish these different aspects of the cultural utility function of culture carriers. The analysis of our second quadrant applies in cases where there is no indication of cultural consumption or additional cultural reproduction by outsiders with an identity-destroying effect (cases above the acceptability-line). As an example, take the noble stratum of the Toraja society, marapuan, who are identified by owning a tongkonan, a traditional Toraja house. The tongkonan is an impressive and complex structure; the creation of such a building requires skill and vast resources. ${ }^{54}$ The noble marapuan enjoy the privileges of decorating their houses in a special way (with paintings and carvings) and pursuing funeral rituals. The size of the tongkonan and the quality of its decorations, carvings and paintings displays rank, honor, and social prestige. ${ }^{55}$ Large-scale emigration in the 1970 s and the resultant remittances sent home changed the social landscape-Toraja families of low status were now able to build large tongkonans and organize expensive, imposing funeral ceremonies (thus acting as additional culture reproducers). These in turn attracted a growing number of foreign tourists (as outsider consumer). The noble marapuan are critical of this development and would like to protect their traditional social position, ${ }^{56}$ which is closely related to the rights to build tongkonans and organize imposing funeral rituals. Nevertheless, previous research does not reveal the extent to which the nobility seeks protection of its privileges. ${ }^{57}$ The identity-providing effect is in fact clear, but seems to be rising with the number of outsider consumers. Thus, there is no clear reason to believe that the fundamental part of the group's identity or dignity is affected. Therefore, the overall economic effect for the whole region is higher, if additional culture reproducers enter the market and attract more tourists. Its distributional consequences for society and the reinvigorating effect on tradition are additional positive effects of no protection.

In the fourth quadrant (IV) are cases in which outsiders cause positive effects on the direct part of utility and at the same time induce losses in indirect utility. Above the acceptability-line as in the third quadrant are cases for which the analysis of the second quadrant should be applied. Below the line an example could be the case of "selling one's soul to the devil," 58 which in spite of causing identitydestroying effects still has some positive effects with respect to payment. In the story of Timm Thaler or the Sold Laughter ${ }^{59}$ the youthful protagonist sells his laughter to an impersonation of the devil and consequentially wins every bet, but soon discovers the value of his laughter and wants to cancel the transaction. At least as long as transactions are completely voluntary and do not exploit the situation (the devil entices a youngster to sell his laughter), such cases in the fourth quadrant might remain an exception because cultural carriers will weigh the positive direct effects against the negative identity effects and can decide for themselves. Further regulation is required only if representation within groups is problematic. Apart 
from that, another example for a good containing a strong identity or dignity character attached to its culture carriers is to be considered. For example, the peak of the Kailas Mountain has not been climbed because of its sacredness. ${ }^{60}$ Nevertheless, outsider tourisms would generate revenues for both the culture carriers and the whole region. On the other hand, climbers or other persons on the top would destroy the soul and dignity of the culture carriers. In such a scenario a protectionworthy good exists and requires additional protection measures justified by the negative impacts on the identity and dignity of the culture carriers.

This classification based on direct and indirect utility effects shows that only cultural goods of the third and fourth quadrants need protection. Within these quadrants we have distinguished between cultural goods that influence the fundamental identity and thereby dignity of a person or a group, consequently requiring protection, and cultural goods for which a cost-benefit analysis can help to find an optimal solution (regarding whether consumption or production for outsiders can be allowed). In these latter cases additional regulation may be necessary to adequately represent the interests of the groups involved.

\section{PROTECTION OF CULTURAL GOODS}

Within the debate around the protection of cultural goods, the most important arguments are those that analyze, primarily, trade with cultural goods and the overall economic effects, not the protection worthiness of the cultural goods per se. However, our approach focuses on the characteristic of cultural goods to also provide indirect utility based on identity and dignity. Consequently, we ascertain a protective need first of all only for those cultural goods that are essential to identity and dignity. We come to this result because we recognize a connection between the dignity of the person and certain cultural goods. Indeed, by no means do all cultural goods have a direct influence on the identity and with it the dignity of individuals. Therefore, only few goods are located below the acceptability-line of figure 2 for which additional preventive measures are to be introduced.

Since only a minority of cultural goods require protection, those affecting the fundamental identity and dignity of persons and groups, some questions arise:

1) How can we determine whether a cultural good possesses a fundamental identity- or dignity-providing effect, which would justify protection by law?

As far as different cultural goods belonging to different societies or groups are concerned, no general rule can be applied. The decision of whether a cultural good has this characteristic or not can only be made in a single case analysis by a court of law, in which the interests of culture carriers should be combined with opinions of independent experts and other interested groups. 
The definition of what cultural goods are identity-critical can be determined by the groups themselves. According to the United Nations, cultural groups have the right to take part in the decision-making processes concerning their rights. ${ }^{61} \mathrm{Ba}$ sically, this entails that culture carriers or their representatives must become the most important actors in the process of assessing and recognizing these cultural goods. Culture carriers should have "a legitimate interest in exercising a duty of care or 'stewardship' over resources" ${ }^{62}$ that represents their collective cultural identity or "peoplehood." The sacred goods and spiritual elements, which presumably form the majority of the protection-worthy goods below the acceptability-line, should stand in the center of these investigations. Examining particular cases for such protection must take central stage within the decision process. To take the interest of other parties (outsiders) into account and not to threaten the public domain unnecessarily by granting additional protection for all cultural goods, the secrecy and the connected strong values of these goods to the cultural community must be clearly identifiable. As Carpenter et al..$^{63}$ suggest, in some cases tribal customary law clearly identifies "certain resources as critical to the community and thereby necessitating human care." Of course, this is just one possibility for obtaining evidence of the need for protection of these particular goods.

Summing up, as stated by Brown, ${ }^{64}$ there is a need to separate the claims regarding economic justice and those regarding respectful treatment of cultural elements. Therefore, in cases where the objections of culture carriers against outsider consumption and reproduction of particular goods are not of an economic nature, this could serve as evidence for further investigation of protection-worthiness.

2) If a cultural good does not have any fundamental identity- or dignityproviding effect, how should the market be regulated?

Cultural goods show quite a few similarities to intellectual property, mostly because of their immaterial character. However, protecting cultural goods with the same instruments as intellectual property rights cannot be a suitable mechanism, as criteria of novelty (patents) or individual authorship (copyright) are not met. Some cultural goods like paintings, sculptures, buildings or monuments are safeguarded by the instrument of the UNESCO World Heritage Site. However, while this does not always imply optimal protection, it rather offers commercialization opportunities. ${ }^{65}$ In cases of the first and second quadrants, and above the acceptability-line of the third and fourth quadrants for immaterial cultural goods, where the privacy of the culture carriers is not at stake, the UNESCO Convention for the Safeguarding of Intangible Cultural Heritage ${ }^{66}$ provides an adequate instrument. On the international level, it aims "at ensuring the viability of the intangible cultural heritage" and "to ensure recognition of, respect for, and enhancement of the intangible cultural heritage ... of the communities groups or individuals concerned." However, these legislations are not sufficient for cases located below the acceptability-line. 
3) What role does the international community play within the regulation process for cultural goods under the acceptability-line?

The international community should feel responsible for creating a legal environment, in which particular cases can be scrutinized and enforced. This in turn would facilitate communicating the importance and the role of culture and cultural goods in the respective societies.

Additionally, the market for cultural goods is not limited to a specific country. The actors such as consumers and producers can be situated abroad, thus making multilateral and bilateral international consultations necessary. Brown ${ }^{67}$ argues that a global market also requires a global controlling regime going beyond mere bilateral solutions.

Another challenge consists in the fact that not all societies or indigenous groups are recognized by their own country. The international level could provide a venue for particular cases which require mediation. Particular societies should take the initiative (as a private initiative) in the case of disagreement with their own government. Otherwise, the state level is entitled to solve the problem. The Indigenous Caucus of the WIPO provides a stage with which international attention can be attracted, in which NGOs (nongovernmental organizations) and indigenous groups from the whole world point to the problem of insufficient protection of cultural goods.

4) What kind of rights can be granted for culture carriers' cultural goods that are worthy of protection?

Speaking only about cultural goods under the acceptability-line, negative effects on identity and dignity need to be avoided. For this, culture carriers are required to be able to control and supervise the consumption of their cultural goods by outsiders and restrict access to their holy or spiritual cultural goods, which are strongly connected to their identity or dignity. Because of the special nature of these cultural goods, general property rights are not a sufficient tool to prevent the commercialization of cultural goods. However, property rights are required to exclude others from consuming and producing these cultural goods. Thus, to some extent, searching for such "defensive" legal instruments as suigeneris rights seems to support these goals. The international regime has already turned its focus on these special property rights granting moral rights to culture carriers while recognizing group ownership and ensuring protection lasting in perpetuity. ${ }^{68}$ Under the auspices of WIPO, the elaboration of a draft proposal for sui generis rights for the protection of traditional cultural expressions (TCEs) ${ }^{69}$ (defined as of material or immaterial nature, or a combination of these) is currently on the agenda. Article 3 (alternative 3 ) of this preliminary version addresses to some extent the mentioned cultural goods proposing a provision of "adequate and effective [legal or practical] measures ... to prevent the [unauthorized fixation, disclosure, use or other exploitation] disclosure of secret traditional cultural expressions," while as overall objectives recogniz- 
ing that these "cultural communities consider their cultural heritage to have intrinsic value, including social, cultural, spiritual ... values" and promoting "respect ... for the dignity, cultural integrity" of these traditional cultures and communities. ${ }^{70}$ Rights to and authority over cultural goods providing identity and dignity (such as secret and sacred cultural goods) is a necessary requirement to keep outsiders out, which thus avoids a consumption and commercialization of these cultural goods by the latter. Granting perpetual rights, as sui generis model laws do, however, is not a preferable solution given the dynamical nature of culture. It requires that people will always ascribe sacredness to certain cultural goods or declare cultural goods as providing identity and dignity. However, culture carriers and their identity are dynamic as well. Some cultural goods lose their meaning to culture carriers over time and the group of culture carriers who value a particular culture good need not be stable. These time limits and community limits (the changing character of groups valuing such goods) are important and should be incorporated in the legislation to avoid the additional social costs caused by unnecessary curtailing of the public domain.

\section{CONCLUSION}

The international debate on the protection of cultural goods is in need of an answer to the question of what exactly is required to provide specific protection in addition to existing property rights. The international debate focuses on so-called sui generis property rights. ${ }^{71}$ However, in this article we suggest an a priori distinction between direct and indirect effects of cultural goods. Direct effects can be quantified as the monetary value arising from marketing a cultural good. Even though in many cases it is not easy to determine such values, there is a broad literature on values of cultural goods. ${ }^{72}$ Indirect effects occur as negative or positive effects on identity. Indirect effects also include option values, prestige values, and so forth, ${ }^{73}$ which are much more difficult to express in monetary terms.

If only direct effects exist, positive and negative effects should be weighed against each other. Protection should be implemented if net benefits outweigh net costs and if this net gain is higher than in a situation with no protection of cultural goods including the consideration of the utility of all stakeholders. Such an evaluation of net benefits must take place on a case by case basis and cannot be solved by introducing international standards.

If indirect effects do exist, the priority is to check their impact on identity. If identity is affected, it is crucial to determine whether the impacts on identity go as far as seriously impairing the personal fundamental identity or dignity of culture carriers. If and only if this is the case, international norms for cultural protection should be implemented in the form of sui generis rights. We suggest that a serious impact on dignity can be assumed if the culture carriers show, for example, serious efforts to keep a certain cultural good a secret. The respective acceptability- 
line must be established by the particular states and groups based on cultural borders and local specifics.

All in all, we conclude that in very limited cases, cultural goods may require additional protection in the form of sui generis rights. However, the introduction of sui generis cultural property rights on an international level should be restricted only to cases where the dignity of culture carriers is seriously endangered. This has the advantage of not threatening the public domain and thus upholding the valuable dissemination of cultural knowledge and innovation. Beyond this category, however, there is a wide field in which regulatory interventions can facilitate the arrival of market actors at sensible decisions.

\section{ENDNOTES}

1. UNESCO Convention (2005), Article 1(a) and (g).

2. See the resent achievements on the yoga dispute at WIPO: WIPO, "WIPO and India Partner or WIPO, "About the Traditional Knowledge Digital Library."

3. Akerlof and Kranton, "Economics and Identity."

4. The utility function is described as $U_{j}=U_{j}\left(a_{j}, a_{-j}, I_{j}\right)$.

5. Akerlof and Kranton, "Economics and Identity," 721.

6. Akerlof and Kranton, "Economics and Identity," 725.

7. The difference between social category and social group is explained in Davis, Theory of the Individual in Economics. There exist internalist and externalist types of definition of the individual (p. 17). "Defining individuals as socially embedded explains them in terms of their external relations to one another": the difference between social categories and social groups is of importance to signal this embeddedness.

8. Francois and van Ypersele, "On the Protection of Cultural Goods."

9. See also Francois and van Ypersele, "On the Protection of Cultural Goods."

10. Janeba, "International Trade and Cultural Identity."

11. UNESCO Convention (2005), 1.

12. Cheng, "Cultural Goods Creation," 264.

13. UNESCO, Universal Declaration (2001), Article 8.

14. This article does not address the question of who belongs to such a cultural group, it rather assumes that a group is homogeneous and values a particular cultural good homogeneously. Deviating behaviour and its impacts within the group is not part of this analysis.

15. Frey, "What Values Should Count in the Arts?" 265.

16. See Koppel, "Patente-Unverzichtbarer Schutz Geistigen Eigentums”; Liebig, "Geistige Eigentumsrechte aus der Perspektive der Entwicklungsländer."

17. To judge whether a particular cultural good (such as a story or a song) belongs to one particular culture and whether this culture (cultural group) is the only beneficiary to commercialize it, is not a subject of this article. See discussion about this topic in Young, Cultural Appropriation and the Arts; Brown, Who Owns Native Culture?

18. Further classification of the utility of outsiders into direct and indirect utility is not necessary since in the case of outsiders the acceptance of identity in regard with a particular cultural good emerging from insiders is not of relevance.

19. In this case, social costs should be understood as loss of utility by exclusion from consumption and the follow-up costs such as limitation of public domain, and thus the restriction of creativity and innovation. See Lechner et al., "The Allocation of Property Rights."

20. As the individuals of the particular cultural group value a specific cultural good similarly, the culture carriers share the same cultural identity. 
21. Frey and Meier, "The Economics of Museums," 1022.

22. Akerlof and Kranton, "Economics and Identity"; Akerlof and Kranton, "Identity and the Economics of Organizations."

23. Throsby, "Determining the Value of Cultural Goods."

24. See Janeba, "International Trade and Cultural Identity."

25. Harrison, "Identity as a Scarce Resource." 240.

26. Also, we are aware of the fact that the conceptual definitions serve as a tool for operationalization. However, the ethnographically documentable social environment is provided with far less clear border drawings.

27. See Janeba, "International Trade and Cultural Identity."

28. At this point, we neglect the negative effects, because as a rule the "new Christians" earlier belonged to another religion, with which they then caused a suitable utility loss.

29. de Beus, "The Value of National Identity."

30. Harrison, "Identity as a Scarce Resource"; Brown, "Heritage Trouble."

31. Throsby, "Determining the Value of Cultural Goods," 276.

32. See Janke, Minding Culture: Case Studies, case study 3.

33. See Meijl, "Maori Intellectual Property Rights"; or further discussion "Tyson's Moko Draws Fire From Maori," New Zealand Herald. 〈http://www.nzherald.co.nz/nz/news/article.cfm?c_ $\mathrm{id}=1$ \&objectid=10727836 $(25$ May 2011) accessed on 2 August 2011.

34. See Pritchard, Culture, Knowledge, Property, 51-84.

35. Lazear, "Culture and Language."

36. Ridler, "Cultural Identity and Public Policy."

37. See the investigation of this issue in Young, Cultural Appropriation and the Arts; Carpenter et al., "Clarifying Cultural Property."

38. Mas-Colell, "Should Cultural Goods Be Treated Differently?"

39. WFTO, IFAT Standards (2007).

40. Janke, Minding Culture: Case Studies, $20 \mathrm{ff}$.

41. Riley, A. R., "Sucking the Quileute Dry," New York Times, February 82010.

42. See Carpenter et al., "Clarifying Cultural Property."

43. See Riley, "Sucking the Quileute Dry."

44. de Beus, "The Value of National Identity," 177.

45. United Nations Declaration (2007), Article 33.

46. United Nations Declaration (2007), Article 15.

47. United Nations Report (2000), Principle 4.

48. Rehfeld, “Tod in der Heiler-Welt," Financial Times Deutschland, 22 October 2009.

49. See Brown, Who Owns Native Culture? 6.

50. See Brown, Who Owns Native Culture?

51. Further differentiation of outsider consumers (such as on the national or international level) is also possible and adds more parameters to the maximization task.

52. United Nations Report (2000).

53. Harrison, "Identity as a Scarce Resource"

54. Scarduelli, "Dynamics of Cultural Change," 390ff.

55. Scarduelli, "Dynamics of Cultural Change," 392.

56. Adams, "Constructing and Contesting Chiefly Authority."

57. Oral communication from field studies in Indonesia by Beate Engelbrecht (2009).

58. Ejan Mackaay pointed this out at a conference held near Göttingen, Germany, on 12-15 November 2009.

59. Krüss, Timm Thaler oder Das Verkaufte Lachen.

60. For some ideas about the Kailas Mountain, see Hamsa, The Holy Mountain.

61. United Nations Declaration (2007), Articles 2 and 18.

62. See in Carpenter et al., "Clarifying Cultural Property," 582, referring to Carpenter et al., "In Defense of Property."

63. See Carpenter et al., "Clarifying Cultural Property," 587. 
64. See Brown, Who Owns Native Culture? 234.

65. See discussions in Berger, Erb.Gut?

66. UNESCO Convention (2003), Art. 1(a), (b), and 14(a).

67. Brown, "Heritage Trouble."

68. See discussion in Bizer et al., "Sui Generis Rights."

69. WIPO, The Protection of Traditional Cultural Expressions: Draft Articles (2011).

70. See WIPO (2011), The Protection of Traditional Cultural Expressions: Draft Articles, Objectives (i) and (ii).

71. Brown, "Heritage Trouble."

72. See, for instance, Throsby, "Determining the Value of Cultural Goods"; Frey, "What Values Should Count in the Arts?"

73. See Frey and Meier, "The Economics of Museums."

\section{BIBLIOGRAPHY}

Adams, Kathleen M. "Constructing and Contesting Chiefly Authority in Contemporary Tana Toraja, Indonesia.” In Chiefs Today, edited by Geoffrey Miles White and Lamont Lindstrom, 264-75. Stanford, CA: Stanford University Press, 1997.

Akerlof, George A., and Rachel E. Kranton. "Economics and Identity." The Quarterly Journal of Economics 115, no. 3 (2000): 715-53.

—. "Identity and the Economics of Organizations." Journal of Economic Perspectives 19, no. 1 (2005): 9-32.

Berger, Karl C. Erb.Gut? Kulturelles Erbe in Wissenschaft Und Gesellschaft; Referate Der 25. Österreichischen Volkskundetagung Vom 14-17.11.2007 in Innsbruck. Edited by Karl C. Berger, Margot Schindler and Ingo Schneider. Vol. 23, Buchreihe Der Österreichischen Zeitschrift Für Volkskunde; N.S., 23. Wien: Selbstverl. des Vereins für Volkskunde, 2009.

Bizer, Kilian, Matthias Lankau, Gerald Spindler, and Philipp Zimbehl. "Sui Generis Rights for the Protection of Traditional Cultural Expressions Policy Implications.” jipitec 2 (2011).

Brown, Michael F. Who Owns Native Culture? Harvard University Press, 2003.

—. "Heritage Trouble: Recent Work on the Protection of Intangible Cultural Property." International Journal of Cultural Property 12, no. 01 (2005): 40-61.

Carpenter, Kristen A., Sonia K. Katyal, and Angela R. Riley. "In Defense of Property." The Yale Law Journal 118, no. 6 (2009): 1022-125.

_. "Clarifying Cultural Property." International Journal of Cultural Property 17, (2010): 581-98.

Cheng, Sao-Wen. "Cultural Goods Creation, Cultural Capital Formation, Provision of Cultural Services and Cultural Atmosphere accumulation." Journal of Cultural Economics 30, (2006): 263-86.

Davis, John B. The Theory of the Individual in Economics: Identity and Value. London: Routledge, 2003.

de Beus, Jos. "The Value of National Identity." In The Value of Culture, edited by Arjo Klamer, 16686. Amsterdam: Amsterdam University Press, 1996.

Francois, Patrick, and Tanguy van Ypersele. "On the Protection of Cultural Goods." Journal of International Economics 56, no. 2 (2002): 359-69. 
Frey, Bruno S. "What Values Should Count in the Arts? The Tension Between Economic Effects and Cultural Value." In Beyond Price, edited by Michael Hutter and David Throsby, 261-69. New York: Cambridge University Press, 2008.

Frey, Bruno S., and Stephan Meier. "The Economics of Museums." In Handbook of the Economics of Art and Culture, edited by Victor A. Ginsburgh and David Throsby, 1017-47. Amsterdam: Elsevier, 2006.

Hamsa, Bhagwān Shri. The Holy Mountain: Being the Story of a Pilgrimage to Lake Mānas and of Initiation on Mount Kailās in Tibet. With an Introduction by W. B. Yeats. Delhi: Pilgrims Book, 1997.

Harrison, Simon. "Identity as a Scarce Resource." Social Anthropology 7, no. 3 (1999): 239-51.

Janeba, Eckhard. "International Trade and Cultural Identity." NBER Working Paper Series. Cambridge: National Bureau of Economic Research, 2004.

Janke, T. Minding Culture: Case Studies on Intellectual Property and Traditional Cultural Expressions: World Intellectual Property Organization, 2003.

Koppel, Oliver. "Patente-Unverzichtbarer Schutz Geistigen Eigentums.” Wirtschaftsdienst 88, no. 12 (2008): 775-80.

Krüss, James. Timm Thaler Oder Das Verkaufte Lachen [Timm Thaler or the Sold Laughter]. Hamburg: Oetinger, 1962.

Lazear, Edward P. “Culture and Language." Journal of Political Economy 107, no. 6 (1999): S95.

Lechner, Sebastian, Zulia Gubaydullina, and Kilian Bizer. "The Allocation of Property Rights to Intangible Cultural Assets.” In Discussion Paper Series, 1-16. Göttingen: Universität Göttingen, 2008.

Liebig, Klaus. "Geistige Eigentumsrechte Aus Der Perspektive Der Entwicklungsländer: Ein Zwiespältiges Instrument." Wirtschaftsdienst 88, no. 12 (2008): 780-83.

Mas-Colell, Andreu. "Should Cultural Goods Be Treated Differently?" Journal of Cultural Economics 23, (1999): 87-93.

Meijl, Toon von. "Maori Intellectual Property Rights and the Formation of Ethnik Boundaries." International Journal of Cultural Property 16, (2009): 341-55.

Pritchard, Stephen. Culture, Knowledge, Property. North Melbourne, Victoria: Australian Scholarly Publishing, 2008.

Ridler, Neil B. "Cultural Identity and Public Policy: An Economic Analysis." Journal of Cultural Economics 10, no. 2 (1986): 45-56.

Scarduelli, Pietro. "Dynamics of Cultural Change among the Toraja of Sulawesi." Anthropos (2005): $389-400$.

Throsby, David. "Determining the Value of Cultural Goods: How Much (or How Little) Does Contingent valuation Tell Us?” Journal of Cultural Economics 27, (2003): 275-85.

UNESCO. Universal Declaration on Cultural Diversity. Paris: UNESCO, 2001.

. Convention for the Safeguarding of the Intangible Cultural Heritage. Paris: UNESCO, 2003.

Convention on the Protection and Promotion of the Diversity of Cultural Expressions. Paris: UNESCO, 2005. 
United Nations. Commission on Human Rights, Human Rights of Indigenous Peoples, Report of the Seminar on the Draft Principles and Guidelines for the Protection of the Heritage of Indigenous People. Geneva: UN, 2007.

United Nations Declaration on the Rights of Indigenous Peoples. Resolution adopted by the General Assembly 61/295. New York: UN, 2007.

World Fair Trade Organization. IFAT Standards for Fair Trade Organizations. Belgium: World Fair Trade Organization, 2007.

."WIPO and India Partner to Protect Traditional Knowledge from Misappropriation." Geneva/ New Delhi, 2011. 〈http://www.wipo.int//pressroom/en/articles/2011/article_0008.html〉 accessed 18 July 2011

World Intellectual Property Organization. "About the Traditional Knowledge Digital Library (Information Courtesy of the Council of Scientific and Industrial Research)." 〈http://www.wipo.int/ meetings/en/2011/wipo_tkdl_del_11/about_tkdl.html $\rangle$ accessed 18 July 2011.

Intergovernmental Committee on Intellectual Property and Genetic Resources, Traditional Knowledge and Folklore. The Protection of Traditional Cultural Expressions: Draft Articles. Document prepared by the Secretariat. Geneva, 2011.

Young, James O. Cultural Appropriation and the Arts. Wiley-Blackwell 2010. 